\title{
Article
}

\section{Discovering Armenian cinema}

\author{
Mazierska, Ewa Hanna
}

Available at http://clok.uclan.ac.uk/19182/

Mazierska, Ewa Hanna ORCID: 0000-0002-4385-8264 (2017) Discovering Armenian cinema. Studies in Eastern European Cinema, 8 (2). pp. 197-199. ISSN 2040-350X

It is advisable to refer to the publisher's version if you intend to cite from the work. http://dx.doi.org/10.1080/2040350x.2017.1303959

For more information about UCLan's research in this area go to http://www.uclan.ac.uk/researchgroups/ and search for < name of research Group>.

For information about Research generally at UCLan please go to http://www.uclan.ac.uk/research/

All outputs in CLoK are protected by Intellectual Property Rights law, including Copyright law. Copyright, IPR and Moral Rights for the works on this site are retained by the individual authors and/or other copyright owners. Terms and conditions for use of this material are defined in the policies page.

\section{CLoK}

Central Lancashire online Knowledge www.clok.uclan.ac.uk

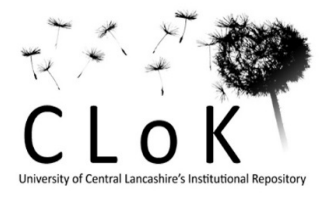




\section{Discovering Armenian Cinema \\ Cinema of Armenia: An Overview. Siranush Galstyan. Mazda Publishers, Costa Mesa, California 2016}

In some ways, Armenian visual culture has a global reach. Canadian Armenian director, Atom Egoyan, is one of the most celebrated arthouse directors worldwide. Also of Armenian origin is also one of the most celebrity families in the world, the Kardashians, with Kim KardashianWest, being labelled 'queen of Instagram'. However, one can argue that these people are not true Armenians, as they live in a diaspora and are second-generation Armenians. In contrast to them, little is known about Armenian cinema and culture produced within its borders. This is sufficient reason to pay attention to the first history of Armenian cinema, published in English, written by leading film historian of this small country, Siranush Galstyan.

Being the first brings both obligations and advantages. On the one hand, it requires the author to provide the readers with the basic information on a given topic; on the other hand, it allows her to indulge in personal preferences, knowing that it is unlikely that her knowledge or ideological position will be challenged. Galstyan fulfilled her duty by writing a very readable and informative, yet not simplistic introduction to Armenian cinema. Her book has a largely chronological structure, charting the main periods and movements in the history of Armenia and its cinema, from its birth in the beginning of the twentieth century to contemporary times. Understandably, the largest part of it constitutes cinema under Soviet rule, given that Armenia was one of its republics, incorporated into the Soviet Union in 1922. The author dedicates several chapters to leading Armenian film auteurs, such as Hamo Beknazaryan, Sergei Parajanov and Artavazd Peleshyan. There is also one devoted to Armenian documentary films and an appendix about Armenian animation. Specific movements and phenomena are discussed against the background of Armenian history, although a reader unfamiliar with it may wish to get more information, especially about Armenia's position as a country on the borders of Europe, perched between Orient and Occident, a Christian enclave surrounded by people of different religious faiths (mainly Muslims) and a larger political, economic and military power.

This position, as Galstyan demonstrates, is reflected in the careers and attitude adopted by the leading Armenian filmmakers. The majority of them she describes using the oxymoron 'cosmopolitan patriots'. The first part of this term refers to the fact that most of them travelled widely in their lives, making films in different parts of the Soviet Union, and that their films were based on foreign sources, such as Georgian novels or Russian poems. However, as the word 'patriot' signals, whenever circumstances allowed, they returned to Armenia and dealt with specifically Armenian topics, showcasing the treasures of the country's culture, architecture and landscape. This is the case of Beknazaryan, Sergei Paranajanov and, to some extent, Egoyan, although the last one is not considered in this book. For example, Hamo Beknazaryan, to whom the second chapter is devoted, was first an actor playing in films of such famous Russian pre-Revolutionary directors as Yevgeni Bauer and Ivan Perestiani, then a director in Georgia and finally an organiser of Armenian film industry in the 1920s, when Armenia became a Soviet Republic. By the same token, these filmmakers were able to look at their country from both inside and outside, and faced the problem of how to represent it in a way satisfying different types of audiences: 'natives' and 'tourists', nationalists and cosmopolitans. Galstyan is well aware of this dilemma and on numerous occasions points to the innovative ways the directors framed the semi-oriental Armenian culture. For example, the narratives of the films she discusses frequently revolve around a woman's 'honour' which is 
violated by her having pre-marital sex or simply falling in love with the wrong man. At the same time, she shows that this motif, pointing to Armenia's social backwardness, is treated in a 'modern' way by directors showing sympathy to a female character, attempting to escape the clutches of patriarchy (usually by giving in to romantic love) and avoiding clichéd Orientalism. In relation to Beknazaryan and his film Namus/Honor (1925), which was also the first featurelength film that was produced in Armenia, Galstyan writes: 'Beknazaryan was perhaps the first [filmmaker] to present the Orient without any fairy tales or stereotypes, adornments or "jewelry" (5). What is true about Beknazaryan pertains even more to Parajanov, the most famous Armenian (as well as a Georgian) director and an artist who probably better than anybody else in twentieth-century cinema managed to render folklore 'cool', as opposed to kitsch, largely thanks to using a sophisticated style, which included static shots and non-linear editing.

Galstyan tries to account for every period in the history of Armenian cinema, but pays particular attention to the 1960s, describing this decade as a period of the 'rise of Armenian cinema', thanks to the achievements of Parajanov and Peleshyan and some other directors. In this respect she demonstrates that Armenia was in tune with many Eastern and Western European countries, which during the 1960 s created their own new waves. She also shows that Armenia, despite its peripheral status, was at the forefront of the New Wave revolutions, thanks to experimentation with editing and creating hybrids between documentary and fiction film. Not surprisingly, in the 1960s Armenian cinema attracted most attention from foreign audiences, as testified by her carefully chosen quotations from Jean-Luc Godard, praising Parajanov. One gets the impression that the achievements of the 1960s are not matched by films of the postcommunist period, despite Galstyan presenting them in a favourable light. One wonders if this decline reflects on the specific situation of independent Armenia, such as economic crisis and hence the lack of adequate funding to make high-budget films, or rather some wider trends, such as a decline of an auteurist paradigm and the rise of popular cinema. The parts devoted to documentary and animation give a fuller picture of Armenian cinema and suggest that, as with many small cinemas, these representional modes had above-average importance for creating a national style.

In common with the majority of scholars of Eastern European cinema, Galstyan privileges an auteurist approach, trying to account for the specificity of the most distinguished Armenian directors' work, but at the same time draws attention to the work of cinematographers, actors and composers. Inevitably, there is little space left to discuss the institutional side of Armenian cinema: the organisation of its production, budgets, distribution and exhibition. I shall also add that at a time of austerity, when publishers are unlikely to invest in projects addressed to smaller audiences and try to save on everything, including illustrations, Cinema of Armenia is commendable exception, thanks to using high-class, glossy paper and being adorned by numerous illustrations, both colour and black and white. They not only perfectly illuminate Galstyan's text, but give insight into Armenian culture and landscape. This is, as one might guess, due to the support of grants from two institutions: the A.K Jabbari Charitable Trust and the National Association for Armenian Studies and Research. Let's hope that they will continue to support scholarship on screen cultures of this fascinating country.

Ewa Mazierska, University of Central Lancashire. School of Humanities and Social SciencesGreenbank Building, GR 23, Preston PR1 2HE, UK. EHMazierska@uclan.ac.uk 